\title{
Early Gondwanan connection for the Argentine Precordillera terrane
}

\author{
Stan Finney ${ }^{\mathrm{a}, *}$, James Gleason ${ }^{\mathrm{b}}$, George Gehrels ${ }^{\mathrm{c}}$, Silvio Peralta ${ }^{\mathrm{d}}$, \\ Guillermo Aceñolaza ${ }^{\mathrm{e}}$ \\ a Department of Geological Sciences, California State University at Long Beach, Long Beach, CA 90840, USA \\ b Department of Geological Sciences, University of Michigan, Ann Arbor, MI 48109, USA \\ c Department of Geosciences, University of Arizona, Tucson, AZ 85721, USA \\ d CONICET, Universidad Nacional de San Juan, 5400 Rivadavia, San Juan, Argentina \\ e CONICET, Universidad Nacional de Tucumán, Tucumán, Argentina
}

Received 13 August 2002; received in revised form 15 October 2002; accepted 27 October 2002

\begin{abstract}
The Precordillera of Argentina is widely accepted as an exotic terrane of Laurentian (North American) affinity. Newly acquired $\mathrm{U} / \mathrm{Pb}$ ages on individual detrital zircons from Lower Cambrian and Upper Ordovician quartz sandstone beds in the Argentine Precordillera indicate a Gondwanan provenance not associated with any known part of Laurentia. Accordingly, the Precordillera terrane is likely underlain by basement rock of Gondwanan affinity. In addition, detrital zircons from the Upper Ordovician sandstone bed provide no evidence for a Mid Ordovician position against the inboard Famatina arc. These results demand critical re-evaluation of widely held assumptions regarding the paleogeography of the Argentine Precordillera.
\end{abstract}

(C) 2002 Elsevier Science B.V. All rights reserved.

Keywords: Argentina; Precordillera; paleogeography; geochronology; Cambrian; Ordovician

\section{Introduction}

Evidence of a Laurentian (North American) affinity for the Argentine Precordillera terrane has stimulated extensive research over the last decade resulting in much discussion and many papers [1-

\footnotetext{
* Corresponding author. Tel.: +1-562-985-8637.

E-mail addresses: scfinney@csulb.edu (S. Finney), jdgleaso@umich.edu (J. Gleason),ggehrels@geo.arizona.edu (G. Gehrels), speralta@unsj-cuim.edu.ar (S. Peralta), insugeo@unt.edu.ar (G. Aceñolaza).
}

12]. The potential for a large exotic continental fragment of North American affinity residing in South America is intriguing in its own right; however, models for the tectonic transfer of this continental fragment have also had a large influence on interpretations of global paleogeography in the early Paleozoic [4]. In the most widely accepted model, the so-called 'funeral ship' model of Thomas and Astini [3], the Precordillera terrane rifted from the southern margin of Laurentia in the Early Cambrian, drifted across the Iapetus Ocean as a microcontinent, and docked with the protoAndean margin of Gondwana in the Mid Ordo- 
vician. In contrast, Dalziel [4] argued for a continent-continent transfer. In his 'calling card' model, the Texas Plateau (a hypothetical promontory of Laurentia) collided with the proto-Andean margin of Gondwana during the early Mid Ordovician. The Precordillera terrane was then detached from the Texas Plateau as Gondwana rifted away from Laurentia in the early Late Ordovician. In both models, the Early to Mid Ordovician Famatinian orogeny is thought to mark the approach and initial encounter of the Precordillera continental fragment with the proto-Andean margin of Gondwana. In an alternative scenario $[6,10]$, the Precordillera was detached from Laurentia during the Mid to Late Ordovician, and did not dock with Gondwana until Silurian-Devonian time. An earlier model suggesting more direct collision between Laurentia and Gondwana (North and South America) during the Ordovician [13,14] has since been discarded based mainly on paleomagnetic and faunal evidence to the contrary [15]. A much earlier model in which the Precordillera terrane was always part of Gondwana [16] has not received any serious recent consideration.

In spite of these different interpretations, the Laurentian affinity of the Precordillera terrane is rarely questioned because it possesses a thick Appalachian-type Cambro-Ordovician carbonate platform succession that contains a 'Pacific' benthic olenellid trilobite fauna, otherwise known only from Laurentia [17-19], as well as similar warm-water conodont and brachiopod faunas [20,21] and reef and reef-mound facies [10]. In addition, limited data suggest that the Precordillera terrane is underlain by Grenvillian-age basement rocks of Laurentian affinity [22].

In this paper, we challenge this widely held interpretation. Recently acquired $\mathrm{U} / \mathrm{Pb}$ ages on individual detrital zircons from Lower Cambrian and Upper Ordovician quartz sandstone beds in the Argentine Precordillera and from a Middle Cambrian(?) to lowest Ordovician quartz sandstone bed in the Sierras Pampeanas indicate a distinctive Gondwanan provenance not associated with any known part of Laurentia. These data strongly support an early Gondwanan connection for the Precordillera terrane. The compelling Laurentian paleobiogeographic affinity of the Precor- dillera terrane must then be explained. Two explanations present themselves: either the Precordillera (1) occupied a northern, low-latitude position in West Gondwana (early Paleozoic coordinates), rather than Laurentia, or (2) had a much more complicated odyssey involving separation from Gondwana and transfer to Laurentia during the breakup of the Pannotia supercontinent, followed by return to Gondwana in the mid Paleozoic. In addition, our new detrital zircon data argue against the widely held interpretation $[1,3,8]$ that the Famatina system, a subduction-related magmatic arc, developed in response to the convergence, and Mid Ordovician docking, of the Precordillera. Instead, our data support interpretations that the Precordillera did not arrive at its present location relative to the Famatina system until sometime between late Ordovician and Devonian $[6,10,16]$.

\section{Analytical methods}

Zircons were analyzed with a Micromass Isoprobe Excimer laser-ablation multicollector ICPMS equipped with nine Faraday collectors, an axial Daly detector, and four ion-counting channels. Analyses were conducted in static mode with ${ }^{204} \mathrm{~Pb}$ measured in an ion-counting channel while ${ }^{206} \mathrm{~Pb},{ }^{207} \mathrm{~Pb},{ }^{208} \mathrm{~Pb},{ }^{232} \mathrm{Th}$, and ${ }^{238} \mathrm{U}$ were measured with Faraday detectors. The analyses were conducted with 50 micron spots, with a total measurement time of $\sim 90$ s per analysis. Inter-element fractionation was monitored by analyzing fragments of a large concordant zircon crystal with a known (ID-TIMS) age of $564 \pm 4 \mathrm{Ma}$ ( $2 \sigma$ error) (G.E. Gehrels, unpublished data). Common $\mathrm{Pb}$ corrections were made with measured ${ }^{204} \mathrm{~Pb}$, assuming an initial $\mathrm{Pb}$ composition according to Stacey and Kramers [23]. Reported ages are based on ${ }^{206} \mathrm{~Pb} /{ }^{238} \mathrm{U}$ for ages less than $1.0 \mathrm{Ga}$, and on ${ }^{206} \mathrm{~Pb} /{ }^{207} \mathrm{~Pb}$ for ages $>1.0$ $\mathrm{Ga}$. Total uncertainty for these ages is $\sim 2 \%(1 \sigma)$. $\mathrm{U} / \mathrm{Pb}$ ages shown in the plots of the La Cébila, Cerro Totora, and Las Vacas samples are mostly concordant, with some up to $15 \%$ discordant. Grains with $\mathrm{U} / \mathrm{Pb}$ ages that were more than $15 \%$ discordant, or that have large uncertainties, were 
excluded from the data set (approximately $10 \%$ of all grains).

\section{Terminology}

Ordovician chronostratigraphic terminology is confusing. The widely used British Series were not well defined, and their definitions have been revised often. Because of marked paleobiogeographic differentiation of Ordovician faunas, independent chronostratigraphic subdivisions have been established for almost every paleo-plate. The geologic history of the Argentine Precordillera is usually expressed in terms of British Series, yet British Ordovician faunas are endemic, thus making correlations to the Precordillera successions inaccurate. We have chosen to use the new global Ordovician Series that are being re-defined by the International Subcommission on Ordovician Stratigraphy (ICS) [24], and which are shown in the Geological Time Scale posted on the ICS website (http://www.micropress.org/stratigraphy/). As recently recommended by ICS, Middle Ordovician and Mid Ordovician are used for the series and its correlative epoch, respectively. We use the geochronologic ages that are in the ICS Geological Time Scale and those presented in Cooper [25]. We note that the integration of geochronologic ages with the global Ordovician chronostratigraphic units differs from that used in several earlier publications on the Precordillera.

By referring to the Pannotia landmass in this paper, we mean the short-lived, latest Precambrian supercontinent that existed immediately following the opening of the Pacific Ocean basin, after the breakout of East Gondwana from Rodinia and its subsequent amalgamation with West Gondwana. See figure 12 in Dalziel [4].

\section{Samples, results, interpretations}

\subsection{La Cébila}

Our La Cébila sample is from a large outcrop of the La Cébila Formation along La Cébila creek, which separates the Sierra de Ambato in
Catamarca Province to the north from the Sierra de Velasco in La Rioja Province to the south (Fig. 1). Both ranges are part of the Sierras Pampeanas immediately east of the Sierra de Famatina. The age of the unfossiliferous La Cébila Formation is uncertain, and it has been correlated to either the Upper Neoproterozoic-Lower Cambrian Puncoviscana Formation or the Middle to Upper Cambrian Mesón Group [26,27]. The age distribution of detrital zircons, presented below, demonstrates that the La Cébila Formation is lowest Ordovician $(<480 \mathrm{Ma})$, and it might be correlative, at least in part, with the Middle to Upper Cambrian Mesón Group, which also is generally unfossiliferous. The La Cébila Formation is composed of mature siliciclastic sediments deposited in a shallow marine platform environment. Given its age and geographic and geologic setting, it was likely deposited on the Gondwanan margin, and must overlie the Neoproterozoic to early Cambrian Puncoviscana Formation, which was deformed during the Pampean Orogeny, 530-520 Ma [6]. The sediment of the La Cébila Formation was probably derived in part, and reworked from, the Puncoviscana Formation, which is a thick meta-sedimentary sequence also interpreted to have a Gondwanan provenance (i.e., the Amazonian craton).

The detrital zircons of the La Cébila sample (Fig. 2) fall into three broad groups of declining abundance that represent the following sources: (1) 0.48-0.72 Ga grains likely derived from intrusions of the Pampean Orogeny, reworked Puncoviscana sediments, and possibly sediment derived from extensions of Brasiliano/Pan-African orogenic belts between the older cratons of West Gondwana, (2) 1.05-1.48 Ga grains representing Grenvillian age-equivalent terranes within Gondwana, perhaps part of the Sunsas orogenic belt of the Amazonian craton or the Kibaran belts of the Congo and Kalahari cratons, and (3) 1.90-2.30 Ga grains likely derived from older Transamazonian/Birimian age terranes [28-33]. In the 0.48$0.72 \mathrm{Ga}$ group, the youngest peak $(480-520 \mathrm{Ma})$ overlaps in age (earliest Ordovician) with, and the detrital zircons could have been eroded from, the earliest magmatic units (515-450 Ma [34] or 490 $450 \mathrm{Ma}[35])$ of the Famatina arc. These granitic 


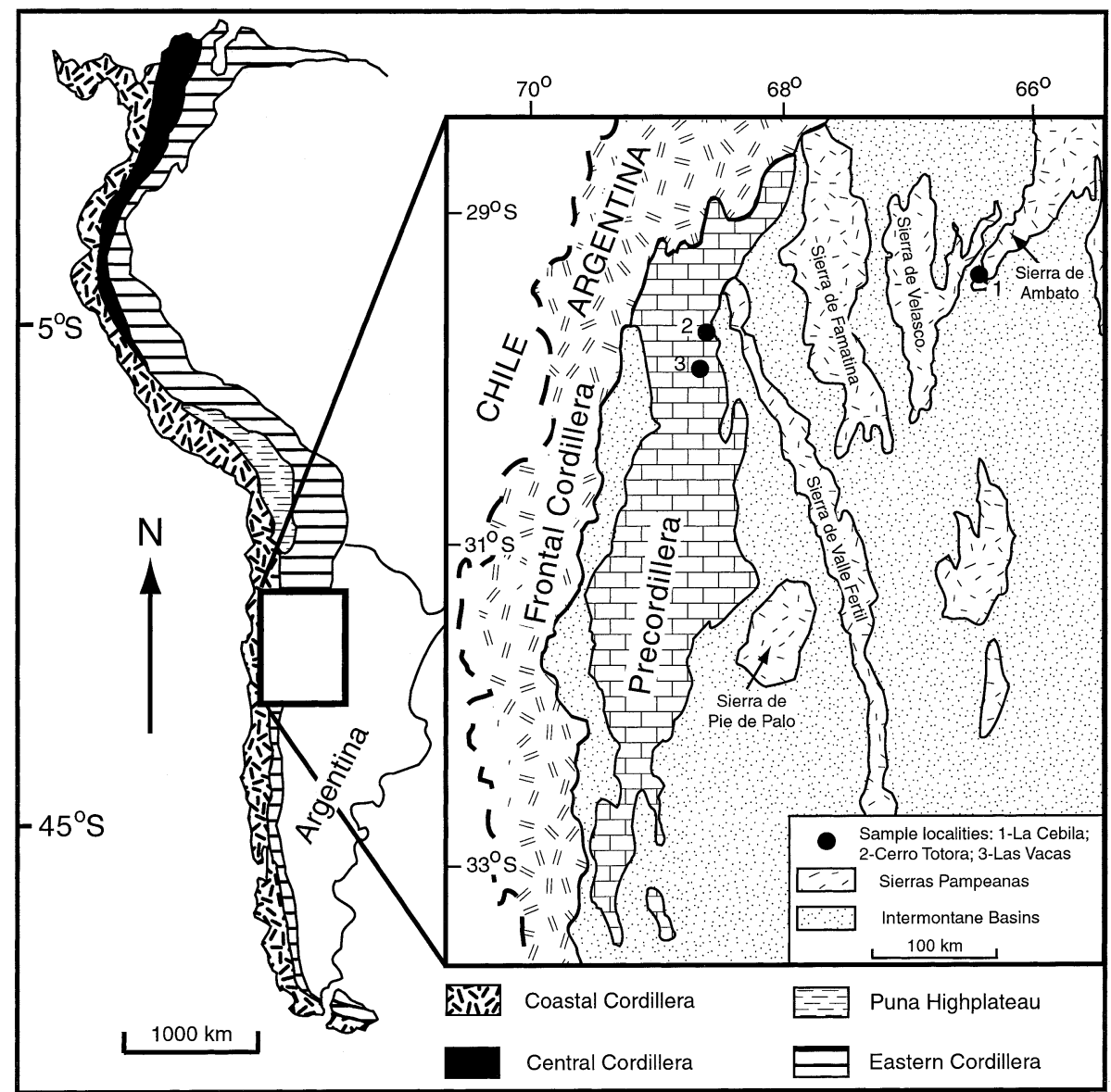

Fig. 1. Index map showing the location of La Cébila, Cerro Totora, and Las Vacas samples in Sierras Pampeanas and Precordillera of northwest Argentina. Substantially modified from Astini et al. [1].

to tonalitic rocks are widespread in the western Sierras Pampeanas especially to the west of the depositional site of the La Cébila Formation in close proximity to the proto-Andean margin of Gondwana. The Grenvillian age-equivalent population, with its broad group that includes distinctive peaks at 1.30 and $1.45 \mathrm{Ga}$, is markedly different from Grenvillian populations of detrital zircons from the Ouachita orogen and Appalachian river sediments of North America, which are concentrated in a narrow group (0.95-1.25 Ga) with a large peak at 1.02-1.05 Ga (Fig. 2). These differences allow for the ready differentiation of Grenvillian-age populations of Gondwana and Laurentia, respectively. Because of their un- equivocal Gondwanan provenance, detrital zircon populations in the La Cébila sample are a critical reference for evaluating the two samples from the Precordillera.

\subsection{Cerro Totora}

The Cerro Totora sample (Fig. 1) is from a well studied outcrop area of the Cerro Totora Formation immediately east of Cerro Totora in the northern part of the Argentine Precordillera [36]. The formation is composed of gypsum and interbedded stromatolitic and oolitic dolostone in its lower part and red silty mudstone, quartzose sandstone and oolitic dolostone in its upper 
part. It is capped by a glauconitic sandstone and an overlying green shale with Early Cambrian olenellid trilobites. The sandstone bed sampled for detrital zircons is within the upper part of an $\sim 30 \mathrm{~m}$ thick interval dominated by red silty mudstone, $\sim 75 \mathrm{~m}$ below the top of the formation. The Cerro Totora Formation is overlain by the Middle Cambrian Hornos Formation (possibly a facies of the widespread La Laja Formation), the lowest unit at Cerro Totora of the thick Cambrian-Lower Ordovician carbonate platform succession, which is characteristic of the Precordillera. The Cerro Totora Formation was interpreted recently as a synrift sedimentary succession deposited in a graben that developed on the Precordillera terrane as it rifted from Laurentia [36,37]. The Cerro Totora Formation is bounded below by a Tertiary thrust fault and is structurally detached from its basement, but that basement is assumed to be Precordilleran (Laurentian) base-

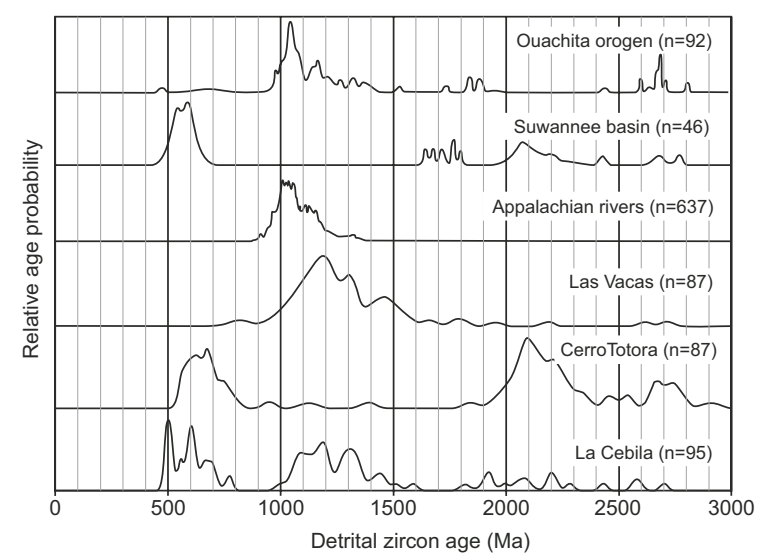

Fig. 2. Relative age-probability curves showing $\mathrm{U}-\mathrm{Pb}$ individual detrital zircon age spectra for La Cébila Formation (Upper Cambrian? to Lower Ordovician), Cerro Totora Formation (Lower Cambrian), and Las Vacas Formation (lower Upper Ordovician), all discussed in this paper. Shown for comparison are $\mathrm{U}-\mathrm{Pb}$ individual detrital zircon age data for US modern Appalachian rivers [52], Ouachita orogen Paleozoic sandstones [53,54], and early Paleozoic sandstone of Gondwanan affinity from the Florida subsurface Suwannee basin [39]. Number of grains analyzed in each sample is shown in parentheses. In this figure, each curve incorporates the age and analytical uncertainty for each grain as a normal probability distribution. Each curve is then normalized to the number of grains analyzed resulting in curves of equal area [55]. ment of Grenvillian age (e.g. 1.0-1.2 Ga) [22]. The contact between the Cerro Totora and Hornos formations is interpreted as a record of the transition in this part of the Precordillera from active rift to passive margin. Given this interpretation for the depositional setting and location of the Cerro Totora Formation, and the widely accepted Grenvillian-age basement of Laurentian affinity for the Precordillera, the detrital zircon age populations in our sample are surprising (Fig. 2).

Most zircons in the Cerro Totora sample correspond chronologically to the Brasiliano/PanAfrican and the Transamazonian/Birimian/Eburnian orogenic cycles. The Brasiliano/Pan-African population $(0.55-0.80 \mathrm{Ga})$ is very similar to that from the La Cébila sample except for the peak in the La Cébila sample of young grains possibly derived from the Famatina arc, reflecting the fact that deposition of the Cerro Totora Formation pre-dated the Famatina arc. The most abundant population of zircons in the Cerro Totora Formation is Early Proterozoic, with a large number of 2.00-2.25 Ga grains, an age range that is distinctive of Transamazonian/Birimian/Eburnian provenance and found only in limited areas of northwesternmost Laurentia (Fig. 3) [38]. The sample also includes a substantial population of Archean grains $(2.40-2.80,2.67-2.75$ Ga). Any signature of a Grenvillian provenance is essentially lacking in this sample, raising serious questions regarding the affinity of the Precordillera basement. The sandstone bed we sampled is a very mature quartzite, suggesting considerable reworking and recycling; yet given its age and geologic setting (both paleogeographic and paleoenvironmental), it must include a substantial component derived from the basement of the Precordillera. Finally, we note that the detrital zircon age population of the Cerro Totora Formation is remarkably similar to that of exotic early Paleozoic sedimentary rocks in the Florida basement (Suwannee basin; Fig. 2), also interpreted as Gondwanan [39]. Based on these data and regional comparisons, we find it difficult to deny an unambiguously Gondwanan provenance for the Cerro Totora Formation and a Gondwanan affinity for associated basement rocks of the Precordillera terrane. 


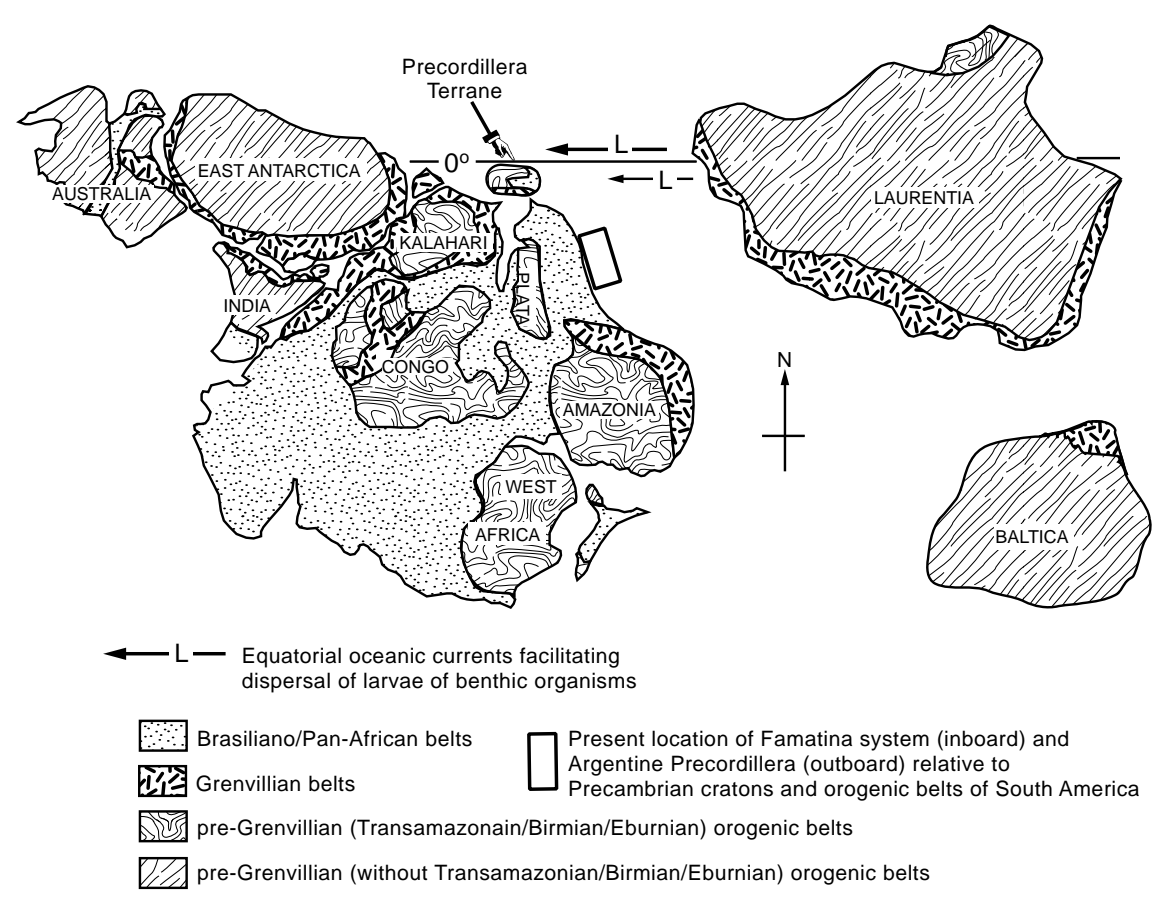

Fig. 3. Early Cambrian ( $\sim 500 \mathrm{Ma})$ paleogeographic reconstruction, modified substantially from Hoffman [46], showing the Gondwanan model for the Precordillera terrane, and the present position (rectangle) of Famatina System and Argentine Precordillera relative to Precambrian cratons and orogenic belts of South America.

\subsection{Las Vacas}

The Las Vacas sample was collected from a bed of quartz arenite in the upper conglomeratic member of the Las Vacas Formation from Quebrada de Las Plantas, a section southwest of Guandacol at the north end of the Precordillera [40]. The Las Vacas Formation, included in the Trapiche Group [1,40], is early Late Ordovician in age ( $\sim 455-458 \mathrm{Ma})$. The sandstone beds are in a thick sequence of basin-fill conglomerate that accumulated in fault-bounded basins. These basins developed atop the Precordillera carbonate platform as it broke apart and foundered in Mid to Late Ordovician time [7,11]. Astini and co-authors $[1,7,11,12]$ interpret basin formation as a response to the docking of the Precordillera terrane with Gondwana in the early Mid Ordovician, which resulted in subsidence of a peripheral foreland basin and drowning of the carbonate platform, followed by post-collisional extension and considerable sediment progradation from the east.
The Las Vacas sample has a large population of Grenvillian-age zircons with an age distribution virtually identical with that of the La Cébila sample and different from populations of Grenvillianage zircons in Ordovician quartz sandstones in the Ouachita orogen and Appalachian river sediments (Fig. 2). Detrital zircons from the Las Vacas sample are concentrated in a single broad group from 1.0 to $1.5 \mathrm{Ga}$ with peaks at $1.19,1.30$, and 1.45 $\mathrm{Ga}$; those of the La Cébila sample also compose a single broad group from 1.0 to $1.5 \mathrm{Ga}$ with peaks at $1.08,1.19,1.30$, and 1.45 Ga (Fig. 2). Accordingly, we conclude that the provenance of the Las Vacas sample must represent a Gondwanan provenance, such as that recorded in the La Cébila sample. We particularly note the absence of detrital zircons less than $520 \mathrm{Ma}$ (Fig. 2), which indicates that the Precordillera terrane was not at its present location close to the Sierra de Famatina during deposition of the Las Vacas Formation.

In addition to carbonate clasts of intrabasinal provenance, the conglomerates of the Las Vacas 
Formation include igneous and sedimentary clasts, which indicate an extrabasinal provenance. As the source of these clasts, Thomas et al. [12] proposed present-day basement rocks exposed in the Sierra de Pie de Palo and Sierra de Valle Fértil (Fig. 1), ranges in the westernmost Sierras Pampeanas, west of the Sierra de Famatina, and considered to represent the eastern part of the Precordillera terrane. The Sierra de Famatina must also be considered as the source of the igneous clasts because of its voluminous igneous rocks of compositions (granodiorite, tonalite, and gabbro) similar to the clasts and because, according to orthodox interpretations $[1,12,34]$, the Famatina arc stood as a topographic high immediately east of the Precordillera terrane in Mid to Late Ordovician time, having formed during Early to Mid Ordovician time as the Precordillera terrane approached and docked with the proto-Andean margin of Gondwana. However, these paleogeographic relationships must be questioned because of the near absence of metamorphic clasts in the Las Vacas conglomerate [41] in contrast to the dominance of Proterozoic-age metamorphic rock in the westernmost Sierras Pampeanas. Because of their textural and mineralogical maturity, the quartz sandstones beds in the Las Vacas Formation must represent a source on the Precordillera terrane that is not known, or they too must have a provenance to the east. The absence of detrital zircons with ages equivalent to the igneous rocks of the Famatina system and the dominance of Grenvillian-age zircons of Gondwanan character in the Las Vacas sample indicate that the provenance of the quartz sand in the Las Vacas Formation, as well as the igneous clasts, was an area of Gondwana far away from the Famatina system.

\section{Discussion}

Most models arguing for the Laurentian affinity of the Precordillera terrane begin with the assumption that the basement of the Precordillera is of Grenvillian age, even though the basement is not exposed anywhere in the Precordillera. This assumption is based on crustal xenoliths from
Miocene lava domes in the Precordillera that have (1) $\mathrm{U} / \mathrm{Pb}$ zircon crystallization ages of 1.102 and $1.118 \mathrm{Ga}$ and (2) whole-rock $\mathrm{Pb}$ isotopic signatures compatible with Grenvillian basement in the Llano uplift along the southern margin of Laurentia [22]. These common $\mathrm{Pb}$ isotopic signatures are widely assumed to be significantly different from nearby areas of South America, particularly basement and volcanic rocks in the Andes [22]. In addition, the basement of the westernmost Sierras Pampeanas (e.g. the Sierra de Pie de Palo and Sierra de Valle Fértil), considered to be the eastern part of the Precordillera terrane, was deformed and metamorphosed during the Grenvillian orogeny as determined by a $U / P b$ upper intercept age of $1.060 \mathrm{Ga}$ for metagneiss [42]. These data represent a very tiny sample of the Precordilleran basement, especially when contrasted with our Cerro Totora sample (87 zircon grains). We believe that the Cerro Totora sample, with its clear Gondwanan affinity, is much more likely to reflect the age of the Precordilleran basement. Similarity of $\mathrm{Pb}$ isotope ratios between the xenoliths of the Precordillera and rocks of the extensive Grenvillian age-equivalent belts throughout Gondwana cannot be ruled out because such comparisons were not made by Kay et al. [22], and, in fact, Wareham et al. [43] reported close similarity of $\mathrm{Pb}$ and $\mathrm{Nd}$ isotope characteristics of Grenvillian-age rocks of Laurentia and the Precordillera to Mesoproterozoic rocks in East and West Antarctica, Natal, and the Falkland Islands. A recent isotopic study of Grenvillian-age basement in the southern part of the western Sierras Pampeanas reveals significant isotopic differences from the Laurentian Grenville [44]. Thus, the widely held assumption of dominantly Grenvillian-age basement of Laurentian affinity for the Precordillera may be untrue.

Our proposed early Gondwanan affinity for the Precordillera terrane is based on only three sampled formations. Although preliminary, they are compelling, positive evidence. Most importantly, the large number of grains analyzed in each sample (87 in both the Cerro Totora and Las Vacas samples) reflects extensive sampling of source areas. If the basement of the Argentine Precordillera is considered Gondwanan, then its 
paleogeographic history must be reconsidered, albeit with the constraints imposed by the sedimentological and paleontological evidence seemingly to the contrary.

The Precordillera continental fragment may have always been part of Gondwana, moving to its present position adjacent to the Famatina system sometime during the latest Ordovician to Devonian. Paleomagnetic evidence from the Cerro Totora Formation has been used to argue that the Precordillera terrane was located at the site of the Ouachita embayment of southern Laurentia in the early Cambrian, and was not close to its present location relative to the rest of South America [45]. However, the only paleomagnetic constraint available is paleolatitude $\left(\sim 20^{\circ} \mathrm{S}\right)$. $\mathrm{Pa}-$ leolongitude is only speculative. Although this paleolatitude is the same as that of the Ouachita embayment, it does not exclude a position in northern Gondwana (Cambrian coordinates). In some Early Cambrian paleogeographic reconstructions $[4,46]$, a northern location in eastern Gondwana would place the Precordillera microcontinent within the tropics with only a narrow ocean separating it from Laurentia (Fig. 3). Such a paleolatitude could account for the thick Cambrian to Lower Ordovician carbonate platform succession of the Precordillera, as well as warmwater tropical faunas. Strong west-flowing equatorial currents would have enabled rapid dispersal of larvae of endemic benthic organisms from Laurentia, resulting in the Laurentian paleobiogeographic affinity of the Precordillera. A later step in this Gondwanan hypothesis would be the migration of the Precordillera microcontinent to its present position adjacent to the Famatina system after the Late Ordovician. Mid to Late Ordovician drowning of the carbonate platform and formation of fault-bounded basins, in one of which the Las Vacas sample accumulated, may record the initial rifting or transcurrent transport of the Precordillera terrane from its original position in northern Gondwana. Its post-Late Ordovician arrival at high paleolatitudes, adjacent to the Famatina system, would be consistent with the paleobiogeography of Mid Ordovician graptolites. Although generally cosmopolitan, these planktonic organisms displayed marked latitudinal provin- cialism in the Mid Ordovician [47,48], with the diverse, low-latitude, Pacific province fauna well represented in the Precordillera stratigraphic successions in sharp contrast to the high-latitude Atlantic province fauna in Ordovician strata of the Eastern Cordillera of Argentina, Bolivia, and Peru $[47,49]$. A low-latitude position for the Precordillera in the Mid Ordovician would be consistent with graptolite paleobiogeography, eliminating the need to invoke long-lived hypothetical oceanic currents to explain the present close geographic juxtaposition of the Atlantic and Pacific faunas in South America [4,47].

Our proposed paleogeographic placement of the Precordillera terrane has antecedents. In 1989, Baldis et al. [16] proposed a similar model in which the Precordillera terrane was displaced along a transcurrent fault from a Mid Ordovician location in northeast Gondwana to a final position adjacent to the Famatina system in the Late Silurian. In the Baldis et al. model, thick successions of extrabasinal siliciclastic sediment of Late Ordovician and Silurian age were delivered successively from Gondwana to the Precordillera terrane as it passed along the proto-Andean margin of Gondwana. Aceñolaza and Toselli [50] also proposed a similar Gondwanan model, and more recently Aceñolaza et al. [51] argued that, because many of the Laurentian faunal elements in the Precordillera also occur in Australia, Antarctica, and on other paleo-plates, the paleobiogeography of benthic fossils of the Precordillera does not preclude a northern Gondwana location.

\section{Conclusions}

Detrital zircon populations in the La Cébila sample are typical of a Gondwanan provenance. They are characteristic of (1) Brasiliano/Pan-African orogenic belts, (2) Grenvillian age-equivalent terranes of Gondwanan, not Laurentian, character, and (3) Transamazonian/Birimian-age terranes. This is consistent with a depositional setting inboard of, and close to, the proto-Andean margin of Gondwana. The abundance of 480-520 $\mathrm{Ma}$ grains is considered as evidence that the La Cébila Formation accumulated in a sedimen- 
tary basin inboard of, and close to, the Famatina arc.

Our sandstone sample from the Cerro Totora Formation has a distinctly Gondwanan provenance with two prominent detrital zircon populations regarded as Brasiliano/Pan-African and Transamazonian/Birimian/Eburnian. Given the geologic setting of the Cerro Totora Formation, the source of zircons must either be the basement of the Precordillera terrane or Gondwana proper, but not Laurentia. If it is the basement of the Precordillera, then the basement rocks are of Gondwanan affinity. If it is Gondwana proper, then the Precordillera must have been adjacent to Gondwana in Early Cambrian time.

The detrital zircon population in the Las Vacas sample is Grenvillian-age equivalent, but the population is very similar to that of the La Cébila sample and significantly different from a Laurentian population (Fig. 2). Thus, it is evidence of a Gondwanan provenance. Because the quartz sandstone of the Las Vacas sample is within a stratigraphic sequence of conglomerates composed in part of extrabasinal igneous and sedimentary clasts with a source to the east, the provenance of the sandstone was to the east. The source area was not the basement rocks presently exposed in the westernmost Sierras Pampeanas because of the scarcity of metamorphic clasts in the Las Vacas conglomerates. Nor was it the Famatina arc because of the lack of age-equivalent detrital zircons. Both the westernmost Sierras Pampeanas and the Sierra de Famatina are directly east of the Precordillera today. But, in Late Ordovician time, the Precordillera must have been removed from its present position relative to these mountain ranges, yet still in position to receive sediment dispersed from Gondwanan basement rocks.

The individual zircon grains of the Cerro Totora and Las Vacas samples represent 174 samples of exposed basement (plutonic) rock incorporated at various stages into the sedimentary system. More samples are needed to test and fully evaluate our results. Nevertheless, given their nature, our results require critical re-evaluation of widely held assumptions regarding the paleogeography of the Argentine Precordillera.

\section{Acknowledgements}

Acknowledgement is made to the Donors of the Petroleum Research Fund, administered by the American Chemical Society, for support of this research. The Radiogenic Isotope Lab at the University of Arizona funded sample preparation and analysis. Universidad Nacional de San Juan provided field vehicle and equipment support. Paul Hoffman, Warren Huff, A.M. Cêlal Sengör, and Ed Stump provided valuable reviews.[SK]

\section{References}

[1] R.A. Astini, J.L. Benedetto, N.E. Vaccari, The early Paleozoic evolution of the Argentine Precordillera, Geol. Soc. Am. Bull. 107 (1995) 253-273.

[2] I. Dalziel, L. DallaSalda, C. Cingolani, P. Palmer, The Argentine Precordillera: a Laurentian Terrane?, GSA Today 6 (1996) 16-18.

[3] W.A. Thomas, R.A. Astini, The Argentine Precordillera: a traveler from the Ouachita embayment of North American Laurentia, Science 273 (1996) 752-757.

[4] I.W.D. Dalziel, Neoproterozoic-Paleozoic geography and tectonics: review, hypothesis, environmental speculation, Geol. Soc. Am. Bull. 109 (1997) 16-42.

[5] R.J. Pankhurst, C.W. Rapela, (Eds.), The Proto-Andean Margin of Gondwana, Geol. Soc. London, Spec. Publ. 142 (1998) 1-383.

[6] C.W. Rapela, R.J. Pankhurst, C. Casquet, E. Baldo, J. Saavedra, C. Galindo, Early evolution of the Proto-Andean margin of South America, Geology 26 (1998) 707 710 .

[7] R.A. Astini, Stratigraphic evidence supporting the rifting, drifting and collision of the Laurentian Precordillera terrane of western Argentina, in: R.J. Pankhurst, C.W. Rapela (Eds.), The Proto-Andean Margin of Gondwana, Geol. Soc. London, Spec. Publ. 142 (1998) 11-33.

[8] V.A. Ramos, R.D. Dallmeyer, G. Vujovich, Time constraints on the Early Palaeozoic docking of the Precordillera, central Argentina, in: R.J. Pankhurst, C.W. Rapela (Eds.), The Proto-Andean Margin of Gondwana, Geol. Soc. London, Spec. Publ. 142 (1998) 143-158.

[9] V.A. Ramos, J.D. Keppie, (Eds.), Laurentia-Gondwana Connections before Pangaea, Geol. Soc. Am. Spec. Pap. 336 (1999) 1-276.

[10] M. Keller, Argentine Precordillera: Sedimentary and Plate Tectonic History of a Laurentian Crustal Fragment in South America, Geol. Soc. Am. Spec. Pap. 341 (1999) 1-131.

[11] R.A. Astini, W.A. Thomas, Origin and evolution of the Precordillera terrane of western Argentina: a drifted Laurentian orphan, in: V.A. Ramos, J.D. Keppie (Eds.), Lau- 
rentia-Gondwana Connections before Pangaea, Geol. Soc. Am. Spec. Pap. 336 (1999) 1-20.

[12] W.A. Thomas, R.A. Astini, G. Bayona, Ordovician collision of the Argentine Precordillera with Gondwana, independent of Laurentian Taconic orogeny, Tectonophysics 345 (2002) 131-152.

[13] L.H. DallaSalda, C.A. Cingolani, R. Varela, Early Paleozoic orogenic belt of the Andes in southwestern South America: results of Laurentia-Gondwana collision?, Geology 20 (1992) 617-621.

[14] L.H. DallaSalda, I.W.D. Dalziel, C.A. Cingolani, R. Varela, Did the Taconic Appalachians continue into southern South America?, Geology 20 (1992) 1059-1062.

[15] C. MacNiocaill, B.A. van der Pluijm, R. Van der Voo, Ordovician paleogeography and the evolution of the Iapetus ocean, Geology 25 (1997) 159-162.

[16] B.A. Baldis, S.H. Peralta, R. Villegas, Esquematizaciones de una posible transcurrencia del terrane de Precordillera como fragmento continental procedente de areas pampeano-bonaerenses, Univ. Nac. Tucumán Ser. Correl. Geol. 5 (1989) 81-100.

[17] A.V. Borrello, The Cambrian of South America, in: D.H. Holland (Ed.), Cambrian of the New World, Wiley-Interscience, London, 1971, pp. 385-438.

[18] O.L. Bordonaro, Biogeografía de trilobites Cámbricos en la Precordillera Argentina, Univ. Nac. Tucumán Ser. Correl. Geol. 7 (1980) 25-30.

[19] N.E. Vaccari, Early Ordovician trilobite biogeography of Precordillera and Famatina, western Argentina: preliminary results, in: J.D. Cooper, M.L. Droser, S.C. Finney (Eds.), Ordovician Odyssey: Short Papers for the Seventh International Symposium on the Ordovician System, Pacific Section, SEPM (Society for Sedimentary Geology) Publ. 77 (1995) 193-196.

[20] O. Lehnert, J.F. Miller, J.E. Repetski, Paleogeographic significance of Clavohamulus hintzei Miller (Conodonta) and other Ibexian conodonts in an early Paleozoic carbonate platform facies of the Argentine Precordillera, Geol. Soc. Am. Bull. 109 (1997) 429-443.

[21] J.L. Benedetto, Early Paleozoic brachiopods and associated shelly faunas from western Gondwana: their bearing on the geodynamic history of the pre-Andean margin, in: R.J. Pankhurst, C.W. Rapela (Eds.), The Proto-Andean Margin of Gondwana, Geol. Soc. London, Spec. Publ. 142 (1998) 57-83.

[22] S.M. Kay, S. Orrell, J.M. Abbruzzi, Zircon and whole rock $\mathrm{Nd}-\mathrm{Pb}$ isotopic evidence for a Grenville age and Laurentian origin for the basement of the Precordillera terrane in Argentina, J. Geol. 104 (1996) 637-648.

[23] J.S. Stacey, J.D. Kramers, Approximation of terrestrial lead isotope evolution by a two-stage model, Earth Planet. Sci. Lett. 26 (1975) 207-221.

[24] B.D. Webby, Steps toward a global standard for Ordovician stratigraphy, Newsl. Stratig. 36 (1998) 1-33.

[25] R.A. Cooper, The Ordovician time scale - calibration of graptolite and conodont zones, Acta Univ. Carol.-Geol. 43 (1999) 1-4.
[26] S.M. Espizúa, R. Caminos, Las rocas metamorficas de la Formación La Cébila, Sierra de Ambato, Provincias de Catamarca y La Rioja, Bol. Acad. Nac. Ci. Córdoba 53 (1979) 125-142.

[27] M. Höckenreiner, Die Formation La Cébila und ihr geologisches Umfeld (Sierra de Ambato, NW Argentinien), Thesis, Diplomarbeit Institut für Angewandte Geologie der Ludwig-Maximilians-Universität, Munich, 1998, 96 pp.

[28] M. Boher, W. Abouchami, A. Michard, F. Albarede, N.T. Arndt, Crustal Growth in West Africa at $2.1 \mathrm{Ga}$, J. Geophys. Res. 97 (1992) 345-369.

[29] B.B. BritoNeves, U.G. Cordani, Tectonic evolution of South America during the Late Proterozoic, Precambrian Res. 53 (1991) 23-40.

[30] B.B. BritoNeves, M.C. CamposNeto, R.A. Fuck, From Rodinia to Western Gondwana An approach to the Brasiliano-Pan African cycle and orogenic collage, Episodes 22 (1999) 155-166.

[31] A. Bernasconi, The major Precambrian terranes of eastern South America: a study of their regional and chronological evolution, Precambrian Res. 37 (1987) 107-124.

[32] J. Klerkx, J.-P. Liégeois, J. Lavreau, W. Claessens, Crustal evolution of the northern Kibaran belt, eastern and central Africa, in: A. Kröner (Ed.), Proterozoic Lithospheric Evolution, Am. Geophys. Union and Geol. Soc. Am., Geodyn. Ser. 17 (1987) 217-233.

[33] C.C.G. Tassinari, M.J.B. Jacambira, Geochronological provinces of the Amazonian Craton, Episodes 22 (1999) 174-182.

[34] S.M. Quenardelle, V.A. Ramos, Ordovician western Sierras Pampeanas magmatic belt: record of Precordillera accretion in Argentina, in: V.A. Ramos, J.D. Keppie (Eds.), Laurentia-Gondwana Connections before Pangaea, Geol. Soc. Am. Spec. Pap. 336 (1999) 63-86.

[35] R.J. Pankhurst, C.W. Rapela, J. Saavedra, E. Baldo, J. Dahlquist, I. Pascua, C.M. Fanning, The Famatinian magmatic arc in the central Sierras Pampeanas: an Early to Mid-Ordovician continental arc on the Gondwana margin, in: R.J. Pankhurst, C.W. Rapela (Eds.), The Proto-Andean Margin of Gondwana, Geol. Soc. London, Spec. Publ. 142 (1998) 343-367.

[36] W.A. Thomas, R.A. Astini, R.E. Denison, Strontium isotopes, age, and tectonic setting of Cambrian salinas along the rift and transform margins of the Argentine Precordillera and Southern Laurentia, J. Geol. 109 (2001) 231246.

[37] R.A. Astini, N.E. Vaccari, Sucesión evaporítica del Cámbrico Inferior de la Precordillera: significado geológico, Rev. Asoc. Geol. Argent. 51 (1996) 97-106.

[38] P.F. Hoffman, Precambrian geology and tectonic history of North America, in: A.W. Bally, A.R. Palmer (Eds.), The Geology of North America - An Overview, The Geology of North America A, Geol. Soc. Am., Boulder, CO, 1989, pp. 447-512.

[39] P.A. Mueller, A.L. Heatherington, J.L. Wooden, R.D. Shuster, A.P. Nutman, I.S. Williams, Precambrian zircons 
from the Florida basement: a Gondwanan connection, Geology 22 (1994) 119-122.

[40] R.A. Astini, El Conglomerado de Las Vacas y el Grupo Trapiche de la Precordillera: tectónica distensiva en el Ordovícico Tardío, Rev. Asoc. Geol. Argent. 53 (1998) 489-503.

[41] S.H. Peralta, Estratigrafía y consideraciones paleoambíentales de los depósitos marino-clásticos eopaleozoicos de la Precordillera Oriental de San Juan, XI Congreso Geológico Argentino Actas I (1993) 128-137.

[42] M.R. McDonough, V.A. Ramos, C.E. Isachsen, S.A. Bowring, G.I. Vujovich, Nuevas edades de circones del basamento de la sierra de Pie de Palo, Sierras Pampeanas Occidentales de San Juan: sus implicancias para los modelos del supercontinente proterozoico de Rodinia, XII Congreso Geológico Argentino y II Congreso de Exploración de Hidrocarburos, Mendoza, Actas III (1993) 340-342.

[43] C.D. Wareham, R.J. Pankhurst, R.J. Thomas, B.C. Storey, G.H. Grantham, J. Jacobs, B.M. Eglington, $\mathrm{Pb}, \mathrm{Nd}$, and $\mathrm{Sr}$ isotope mapping of Grenville-age crustal provinces in Rodinia, J. Geol. 106 (1998) 647-659.

[44] A.M. Sato, A.H. Tickyjb, E.J. Llambíasa, K. Satoc, The Las Matras tonalitic-trondhjemitic pluton, central Argentina: Grenvillian-age constraints, geochemical characteristics, and regional implication, J. S. Am. Earth Sci. 13 (2000) 587-610.

[45] A.E. Rapalini, R.A. Astini, Paleomagnetic confirmation of the Laurentian origin of the Argentine Precordillera, Earth Planet. Sci. Lett. 155 (1998) 1-14.

[46] P.F. Hoffman, Did the breakout of Laurentia turn Gondwanaland inside-out?, Science 252 (1991) 1409-1412.

[47] S.C. Finney, X. Chen, The relationship of Ordovician graptolite provincialism to palaeogeography, in: W.S.
McKerrow, C.R. Scotese (Eds.), Palaeozoic Palaeogeography and Biogeography, Geol. Soc. Mem. 12 (1990) 123128.

[48] R.A. Cooper, R.A. Fortey, K. Lindholm, Latitudinal and depth zonation of early Ordovician graptolites, Lethaia 24 (1991) 199-218.

[49] C.E. Mitchell, E.D. Brussa, R.A. Astini, Biogeography of Middle and Upper Ordovician graptolites, Precordillera terrane, Argentina: plate tectonic implications, Geol. Soc. Am. Abstr. with Progr. 29 (1997) A379.

[50] F.G. Aceñolaza, A.J. Toselli, Argentine Precordillera: allochthonous or autochthonous Gondwanic?, Zbl. Geol. Paläontol. Teil I 7/8 (1999) 743-756.

[51] F.G. Aceñolaza, H. Miller, A.J. Toselli, Proterozoic-Early Paleozoic evolution in western South America - A discussion, Tectonophysics 354 (2002) 121-137.

[52] K.A. Eriksson, I.H. Campbell, J.M. Palin, C.M. Allen, The Grenville superorogeny revealed by detrital zircons in Appalachian rivers, Geol. Soc. Am. Abstr. with Progr. 33 (2001) A29.

[53] J.D. Gleason, S.C. Finney, G.G. Gehrels, Paleotectonic implications of a Mid- to Late-Ordovician provenance shift, as recorded in sedimentary strata of the Ouachita and Southern Appalachian Mountains, J. Geol. 110 (2002) 291-304.

[54] J.D. Gleason, G.G. Gehrels, S.C. Finney, Tectonic recycling in the Paleozoic Ouachita Assemblage from U-Pb detrital zircon studies, EOS 82 (2001) 435.

[55] J.H. Stewart, G.E. Gehrels, A.P. Barth, P.K. Link, N. Christie-Blick, C.T. Wrucke, Detrital zircon provenance of Mesoproterozoic to Cambrian arenites in the western United States and northwestern Mexico, Geol. Soc. Am. Bull. 113 (2001) 1343-1356. 